\title{
Relation between Consumer Innovativeness Behavior and Purchasing Adoption Process: A Study with Electronics Sold Online
}

\author{
Anderson Neckel ${ }^{1}$ \& Ricardo Boeing ${ }^{2}$ \\ ${ }^{1}$ Assistant Professor at Passo Fundo University, Brazil \\ ${ }^{2}$ Assistant Professor at the University of Wisconsin - Stevens Point, United States \\ Correspondence: Ricardo Boeing, Assistant Professor at the University of Wisconsin - Stevens Point, United \\ States. E-mail: rboeing@uwsp.edu
}

\author{
Received: May 5, 2017 Accepted: May 24, 2017 Online Published: May 29, 2017 \\ doi:10.5539/ijms.v9n3p64 URL: http://doi.org/10.5539/ijms.v9n3p64
}

\begin{abstract}
This paper aims at analyzing the influence of consumer innovativeness behavior on the purchasing adoption process of products sold on the internet. Through a theoretical framework, the Domain Specific Innovativeness (DSI) and New Involvement Profile (NIP) scales were used in the study. The research approach has a mixed methodology, having both qualitative and quantitative approaches. In the qualitative phase, two focus group were conducted, with the objective of aligning the scales with the main research focus, and in the quantitative phase, an online survey with 448 respondents was applied. Data processing was based on multiple linear regression and results shows that the construct of the consumer innovativeness behavior has an explanatory power $\left(\mathrm{R}^{2}\right)$ of $59.8 \%$ relative to the purchasing adoption process by the consumer. The consumers with a stronger innovativeness behavior showed to have similar characteristics when it came to purchasing innovative electronic products, making it easier to lead them to consumption.
\end{abstract}

Keywords: consumer innovativeness behavior, marketing, purchasing adoption process

\section{Introduction}

According to Mazzon (2011), as time progressed, the consumer behavior has taken on more complex featuresinterconnectedwith the new consumer environment, the so-called electronic commerce. In turn, this environment is made up of different specific groups of consumers, diverse attitudes, habits and manners from one another, which strongly characterize their personality, self-concept and a new lifestyle.

Rogers (1983) recognized a new consumer behavior profile, regarded asbehavior innovativeness, which typifieshim/her as the first to get new ideas, processes and innovative products sooner than other individuals, while being influenced by personal aspects such as self-concept, impulsiveness, personal image and social status.

In their study, Hynes \& Lo (2002), as well as Marez \& Verleye (2004) establish a relationship with the consumer innovativeness behavior, describing the capability of innovation in organizations and the involvement of consumers in such process. The innovation diffusion process is also referred to, yet none of these researchers establishes a relationship of consumer behavior innovativenesswith the purchasing adoption process.

Accordingly, as a theoretical basis, this research is intended to contribute to the theory by using studies introduced by Jain studies and Srinivasan (1990) and Goldsmith \& Hofacker (1991), making a connection between innovativeness behavior and purchasing adoption processon an exploratory study carried outin the states of Rio Grande do Sul and Santa Catarina.

Therefore, there is an attempt to carry out an information measurement on consumer innovativeness behavior vis-à-vis influencing factors of the purchasing adoption process, a framework in which this paper is introduced. As a result, the following research question is proposed: what is the degree of influence of electronics consumer innovativeness behavior sold over the internet on the purchasing adoption process?

In order to answer this research question, the following objectives were defined: Analyzing the influence of consumer innovativeness behavior on the purchasing adoption process; Identifying the consumer innovativeness behavior of electronics and; Pointing out the key influencing factorsassociated with the purchasing adoption process of electronics commercialized by internet. 


\section{Theoretical Background}

In order to approach the major theories encompassing this research, this paper theoretical framework is focusedon the following topics: Consumer behavior, innovativeness behavior and purchasing adoption process.

\subsection{Consumer Behavior}

In the course of time, consumer behavior has undergone various changes, arising both from new consumption practices and a direct influence of communication channels. Entries of new brands into the market, an excess of products with features akin and launching of innovative products have produced new types of consumer involvement in the purchasing process.

The first studies linked to consumer behavior aimed at identifying how consumers would react on the supply and communication processes of certain products, and sought to recognizewhich the procedures performed until the purchasing closing and their influencing factors were, while the society where the consumer is inserted was considered a basic aspect (Grubb \&Grathwohl, 1967; Kassarjian, 1971; Tybout \& Hauser, 1981).

Behavioral influences proposed by society, according to Bearden, Calcich, \& Retemeyer (1985), are behavioral intentions thought to function mainly through a general measure of subjective rules. These, in turn, derive from a combination of normative beliefs, which determine whether a person should or should not behave in a given way, developing a relationship with a reference group. They can also be characterized as interpersonal influences.

Interpersonal influences on consumer behavior, according to Vinson et al. (1977) and Bearden et al. (1985), may exist as a more fundamental unit within a definite group of individuals, as they have continuing actions, concerning beliefs and judgments through specific situations and are referred to as inclusive values. These inclusive values are more abstract, because they make up the group core, consisting of a closedcapital of personal values, which have high significance in evaluations and important choices determining their lifestyle.

According to Kassarjian (1971), the concept of lifestyle is based on different ways or life characteristics of groups in a society, apportioning the market into segments based on interests, values, views, personality traits, attitudes, and demographic variables. The way in which the ego directs the consumption energy and requirements create a wide range of interests, motivations, attitudes and behaviors.Ego defenses generate other outcomes, such as rationalization, projection, identification and repression, while they are integrated directly into action.

An explanation of interpersonal influence on consumer behavior, according to Tybout \& Hauser (1981) and Bearden et al. (1985), has direct correlation with consumer innovativeness behavior, since the purchase intention is directly affected by attitudes and social influences, deriving from a combination of beliefs and behavioral attitudes within a reference group.

As far as Chakrabarti \& Baisya (2009) are concerned, innovativeness behavior is a cognitive style, coming from anidiosyncrasy of the generalized personality (so, unobservable) and reflects the inherent and innovative personality of a person. Then, it can be applied to a number of situations. McMahan, Hovland, \& Mcmillan (2009) describe it as a feature of the situation resulting from basic features and a consumption compound and a history of learning, influencing consumer behavior in consumption situations of innovative products. This construction has also been referred to as "innovative predisposition".

\subsection{Consumer Innovativeness Behavior}

Consumer innovativeness behavior has been broadly debated by numerous experts in the field, by influencing directly contexts regarding consumer behavior due to an easy access to the information created by the media; the purchasing adoption process of innovative products, which due to the easycomparison of products and services, faces certain change; and the planned obsolescence process, a factor created by companies, causing the consumer to purchase and repurchase certain products. For a better understanding onthese processes, first one must evaluate how innovation originated in companies.

The theory of innovation in companies originated from the work of economist Joseph A. Schumpeter, whoreferred to innovation as distinctly different from invention. As far as this economistis concerned, innovation involves the construction of new plants and equipment; establishment of new companies; and the rise of new men to the leadership (Schumpeter, 1942).

Robertson (1967), in his work, describes that behavioral scientists in the 1960s, devoted much attention to the innovation theme, although various contemporary writers stimulated a number of discussions on creativity, particularly on how the creative process occurs within itself. Schumpeter (1942) states that anthropologist HG Barnett depicted innovation as the basis for culture changes, and defines innovation as "any thought, behavior, or 
thing that is new", a concept that is much more comprehensive than that proposed by sociologist Rogers (1968), which extends the definition even further, by referring to the innovation as "a new idea perceived by the individual".

The Oslo Manual (2005), which debates proposed guidelines for collecting and interpreting data on technological innovation, defines four types of innovations encompassing a wide range of changes in the company activities: product innovations, process innovations, organizational innovations and marketing innovations.

Product innovations implicate substantial changes in products and services potentialities. Brand new goods and services and significant improvements to existing products are included. Process innovations represent significant changes in production and distribution methods. Organizational innovations refer to an implementation of new organizational methods such as changes in business practices, workplace organization or external relations of the company. Marketing innovations comprisean implementation of new marketing methods, including changes in product design and packaging, in product promotion and placement, and in pricing methods for goods and services (OECD, 2005).

Consumer innovativeness behavior experiences influence of innovations proposed by organizations and can also be directly related to the aptitude for culture innovation of a specific group, causing a positive effect on individual's innovative capacity. When the group culture is receptive to new ideas, it may be associated with higher levels of innovation. Additionally, the marketing has been increasingly interested in innovation processes, as these determine the course of the new undertaking and the launch of new products (Batory \& Neese, 2005; Tajeddini, Trueman, \& Larsen 2006).

When an innovative product is puton the market, consumers become aware, know their attributes and learn about them, decide about making the purchase and when to do it. According to Engel, Blackwell, \& Miniard (1995), innovativeness can be regarded as the degree to which an individual adopts an innovation relatively earlier than other consumers, directly influencing the purchasing adoption process.

The consumer purchasing behavior towards innovative products might be characterized as the key research factor for launching innovative products.

Wang, Dacko, \& Gad (2008), as well as Tellis, Yin, \& Bell (2009) in their work describe changes in personal traits, such as previous knowledge and innovation capability or social interactions. They also highlight as a word-of-mouth advertisement can influence people's evaluation or forecast of benefits for a new product, assistingin explaining why certainindividuals can evaluate a new product more positively than others.

The consumer-perceived innovation can be an important factor motivating economic progress of an organization and its position in the competition. Tellis et al. (2009) in their study endeavored to identify main items to measure consumer innovativeness, among which are included the search for novelty, a desire for the different and the new, risk-taking and aninclination for running risks or being adventurous. Within this context, risk-taking can be regarded asasignificantelement in consumer behavior, a characteristic also used by organizations to stimulate the internal process of innovation (Wang et al., 2008).

Yang (2010) describes in his study that both innovation and benefits a new product or service can have, directly affects consumer perception, it creates facilities in use and induce purchase. In addition, perceived utility is considered decisive for purchase intentions of American consumers, while for Korean ones, technology is the most important factor in the purchase adoption process.

Tellis et al. (2009) created a definition for consumer behavior with respect to innovation, typifying it as consumer predisposition to adopt new products, and also caused by numerous reasons, because markets are becoming increasingly competitive and the creation of new products follows with an increasing frequency. In this context, companies need to know the propensity of consumers to buy these products. Knowing the innovation behavior can help creating new opportunities concerning the consumer's potential.

Blake, Valdiserri, Neuendorf, \& Valdiserri (2007) in their study identified that the effect of innovation perceived by consumers in online purchasing has been very significant, since this innovation influencesthe purchasing decision-making, since users of this medium are always looking for updates and innovations, price comparison as well as the quality of products and services.

In the purchasing decision process for an innovative product, according to Caro, Mazzon, \& Caemmerer (2010), consumers are moved by a number of factors that foster an innovativeness behavior. Among these are cultural, social, personal and psychological factors, by marketing stimuli and other stimuli interconnectedwith the environment in which theyare inserted, and everyone is changing with new technology; differences between 
online stores and physical stores, in addition to innovative marketing strategies are altering habits and purchasing styles. The purchasing process is changing, justified by the advantages brought by the internet and an easy access to information.

\subsection{Purchasing Adoption Process}

Purchasing adoption process is described as the manner in which consumers adopt a new product, service or innovation. It is a constant subject in most correlated articles, as well as in major consumer behavior studies (Strader \& Hendrickson, 2001). Within this context, consumers have a consumption need which must be satisfied and initiate a series of steps referred to as "decision making process" or "purchasing adoption process".

Caro et al. (2010) statethat it is necessary to know all activities directly involved in putting certain products and services on sales, since there is a decision-making process in relation to the purchasing closing, and to this end,it is necessary to understand each step and also individual factors related to the adoption process of new products or innovative products. Exhibit 1 shows the phases of the consumer purchasing adoption process.

Exhibit 1. Purchasing adoption process

\begin{tabular}{ll}
\hline 01-Identification of need. & Awareness of a given problem. \\
\hline 02-Search of information. & Search in communication channels and physical stores. \\
03-Analysis of alternatives. & Filter of the most relevant information and attributes. \\
04-Definition of purchase. & Purchase of the best alternative. \\
05-Consumption. & Product application. \\
06-Post-purchase evaluation. & Analysis of the purchasing and consumption experience. \\
07-Disposal. & Disuse or resale. \\
\hline
\end{tabular}

Source: adapted from Rogers (1995), Strader \& Hendrickson (2001) and Caro et al. (2010).

The phases of new product adoption process start by identifying a specific problem or need and continue with information search, when individuals collect information from different areas in order to meet their needs. Then, the evaluation of the alternatives occurs, when the attributes of the products and services are compared in order to obtain the most desired ones; the purchasing closing, choosing of a single good or service; consumption; post-purchase evaluation, during which consumers perceive the need to repurchase and share their experiences with others; and, finally, disposal, disuse, resale and identification of a new need (Rogers, 1983; Strader \& Hendrickson, 2001; Horn, 2009).

From this purchasing adoption process, a number of individual factors are also related to the purchasing adoption process for new products or innovative products (Rogers, 1983).

Innovative products are important sources of economic growth for organizations, however, from the consumer's standpoint, these products are labeled as innovations, which defy direct classification in terms of existing product concepts, instigating uncertainty regarding the exchange for a new one, making the consumption process unstable, which somehow makes the understandingof this process more difficult to organizations (Wang et al., 2008).

Kazakeviciute \& Banyte (2012) claim that the purchasing process has become critical in the lives of consumers due to an ever-changing consumer environment influenced by the internet and mainly as anoutcome of electronic commerce. Understanding this factor, derived from consumer behavior, is essential for marketing representatives, because from it, they can position their products in a more suitable manner, promoting customer satisfaction and bigger sales.

For this reason, Jain \& Srinivasan (1990) stress that a decision to purchasing adoption of innovative products varies from one individual to another, according to their individual traits, such as demographic (age, gender, location etc.), socioeconomic (income, social class), psychographic (personality, open mind) and cultural (ethnic, value system) data. Furthermore, other factors eventually directly influence the decision-making process, such as relevance, symbolic value, significance of risk and probability of risk, which are the key focus of this study.

\subsubsection{Relevance}

Relevance refers to the degree of significancea particular product or service has on an individual's life (Jain \& Srinivasan, 1990). It can also be characterized as the satisfaction of purchasing a specific product or service highly desired by consumers (Rogers, 1083).

Relevance has a direct relationship with the intrinsic involvement of a particular brand, directly influencing the 
amount of efforts which will be used for a purchasing closing (Clarke \& Belk, 1979).

Such efforts can manifest in numerous ways: internally, when consumers recover and shall review information previously acquired; or externally, when consumersare concerned in pursuing information through different media (Clarke \& Belk, 1979; Jain \& Srinivasan, 1990).

\subsubsection{Symbolic Value}

The symbolic value is the value perceived by consumers on a particular product or service, it can also be characterized by consumer satisfaction with attributes offered by those consumer goods purchased (Rogers, 1983).

According to Grubb \& Grathwohl (1967), the symbolic value is the major way to understand the role of consumer goods, becoming a social tool, symbols serving as a means of communication between individuals and their references.

Members of a group use consumer goods as symbols in order to express their behavior and showtheir positioningrelative to other individuals. Furthermore, this symbolic classification allows consumers to relate directly to it, matching their self-concept with the meaning of good. In this manner, personality and self-improvement may ensue by association with the goods that have a desirable social meaning and the favorable reaction of significant references in the process of social interaction (Grubb \& Grathwohl, 1967; Jain \& Srinivasan, 1990).

\subsubsection{Significance of Risk}

Significance of risk corresponds to the perception of risk in the purchasing adoption process. In this situation, the consumer has a transitory engagement with a product in the course of the purchasing adoption process, especially when there are high risks associated with the outcomes of such a purchase. The greater the risk, the greater the level of engagement of that consumer is (Rogers, 1983).

The involvement consumers and their behaviors resulting from this connection are defined by Arora (1982) as the search for information in the communication channels. They are directly related to the purchase itself, and not with the product concerned. This way, they embody efforts made to ensure the outcomes of a purchase, which implies that, once the purchase is made and the expected outcomes are found, the engagement is no longer required.

Significance of risk is often perceived when there is a high complexity in the keyfeatures of consumer goods, such as price and attributes, directly influencing the purchasing frequency (Arora, 1982).

\subsubsection{Probability of Risk}

Probability of risk is the possibility that consumers may have in making a wrong purchase. Generally it can take place when an involvement in the purchasing process comes about with low intensity and consumers end up making the purchase without demanding much effort (Jain \& Srinivasan, 1990).

When the influence of other individuals in the purchasing process has a greater intensity, the purchasing closing by consumers can have an unintentional nature, contributing to probability of risk, since desires to buy that particular good may characterize the satisfaction of another person, but not the consumer's ownsatisfaction (Rogers, 1983).

\section{Research Methodology}

As the goal of this research is to analyze both constructs, consumer innovativeness behavior, as well as the purchasing adoption process, exploratory and descriptive research in a mixed approach were applied. The first is described by Alves-mazzotti \& Gewanddsznajer (1999) as unstructured, exploratory research, based on small samples. However, in the second approach, framed in the positivist view of social sciences, the quantitative research can be characterized, according to Malhotra (2012, p. 111) as a methodology pursuing to elucidate processes or phenomena by data quantification, having as a primary goal generalize the sample results.

In order to better understand the topics two discussion groups were organized, both carried out with consumers in southern Brazil. The results were used topreparea questionnaire applied in the second phase of this research. Both meetings were held in July and August 2013, with individuals between 18 and 35 years of age, both sexes, who had made at least one purchase of electronics on the internet in the previous 6 months, totaling 27 participants.

In order to build the theoretical model of this research, in addition to discussion groups in the qualitative phase of the research, a single model was sought that could translate the influence of consumer innovativeness behavior on the purchasing adoption process. 
After reviewing the available literature, the model proposed by Goldsmith \& Hofacker (1991) was decided to be used as a basis for analyzing the consumer degree of innovativeness, because the innovative consumer profile can be termed in accordance with behavioral characteristics that lead these consumers to be the first to buy an innovative product. In this regard, innovative consumers are more interested in the product while being more exposed to information and susceptible to talk to others about the new concept of innovation.

To this scale are aggregated changes that were validated after the exploratory phase of the research and also after performing the pre-test of quantitative data collection instrument. In order to measure the level of consumer innovativeness behavior, to, later on, relate such information with the intention to purchase, the model proposed by Goldsmith \& Hofacker (1991) will be employed, comprising an 11-item scale, adapted to the reality of this study, as shown in Exhibit 2.

Exhibit 2. Innovativeness construct

\begin{tabular}{lll}
\hline Variables & Items & Statements \\
\hline Innovativeness & Q01 & In general, I am among the first person in my circle of friends to purchase an innovative product. \\
& Q02 & If I hear that a new product is available in the store, I become interested enough to purchase it. \\
& Q03 & I enjoy newly launched products. \\
& Q04 & Comparing to my friends, I have a few innovative products. \\
\hline Self-concept & Q05 & If a friend has a newly launched product, I ask to see. \\
& Q06 & In general, I am the last in my circle of friends to know about the innovative products. \\
& Q07 & I usually buy newly launched innovative products. \\
\hline Impulsiveness & Q08 & I like to buy an innovative product even though I have not heard about yet. \\
& Q09 & I don't like buying innovative products launched by new companies. \\
& Q10 & I don't know the names of innovative products before other people know them. \\
& Q11 & I don't like buying innovative productswhich have an original design. \\
\hline
\end{tabular}

Source: Adaptedfrom Goldsmith \& Hofacker (1991).

In order to measure the consumer innovativeness behavior in relation to the purchasing adoption process, the New Involvement Profile (NIP) scale described by Jain \& Srinivasan (1990) was used. These authors claim that a one-dimensional scale is not able to capture the complexity of consumer involvement in the purchasing adoption process. Yet, they propose a new 15-item and 5-dimension scale: relevance, pleasure, symbolic value, significance of risk and probability of risk which have been adapted based on consumer perception and symbolic factors that influence the purchasing adoption process at the time the individual feels the need to purchase an innovative product.

Within this context, the NIP scale was suitable after the exploratory phase for greater compliance with the theme researched, relating the consumer behavior with factors influencing the purchasing adoption processof electronics, as shown in Exhibit 3.

Exhibit 3. Purchasing adoption process

\begin{tabular}{lll}
\hline Variables & Items & Statements \\
\hline Relevance & Q01 & The product is essential. \\
& Q02 & It's beneficial. \\
& Q03 & It's unnecessary. \\
& Q04 & I don't think the product is pleasurable. \\
& Q06 & It's not exciting. \\
& Q07 & It'sfun. \\
\hline Symbolic value & Q08 & Others can judge me because of it. \\
& Q09 & I doesn't show my personality to other people. \\
\hline Significanceof risk & Q10 & It's annoying to make an improper purchase. \\
& Q11 & A bad choice wouldn't be a nuisance. \\
& Q13 & I have little to lose by choosing poorly. \\
\hline Probabilityof risk & When I buy it I am sure of my choice. \\
& Q15 & I never know if I'm making the right purchase. \\
\end{tabular}

Source: Adapted from Jain \& Srinivasan (1990). 
The quantitative phase was carried out through a survey with an online questionnaire, on a page designed specifically for this research. The survey research may be described as obtaining data and information fromspecific groups of individuals by a previously prepared form for a definite purpose (Hair Júnior, Anderson, Tatham, \& Black, 1998).

The prepared questionnaire was pre-testedin two different settings. At the outset, the prepared questionnaire was pre-tested with 55 consumersin order to identify some difficulties in filling out. The second version was used with 52 consumers who had also performed a purchase of an electronic product by internet within the last six months, totaling $13 \%$ of the sample.

Based on the results achieved in the second pre-test, Cronbach's Alpha test was performed to verify the model reliability. According to Hair et al. (1998) this test is used to measure the reliability degree of the analyzed constructs, when the index is greater than 0.6, and the data obtained are suitable for multivariate data analysis. In this way, both constructs had rates above 0.6, and the innovativeness construct achieved (0.847) and the purchasing adoption process $(0.745)$, showing that the model is ready for a quantitative use.

Statistical studies were performed using multivariate data analysis, which is a set of methods and techniques which analyze simultaneously all variables in the theoretical interpretation of a research data set (Malhotra, 2012). For the present study, there was the option for multiple linear regression analysis, which aims at identifying the best relationship between the response variables and a set of explanatory variables. According to Hair et al. (1998), the multiple linear regression is a statistical technique that can be used to analyze the relationship between a single dependent variable and several independent variables. For rotation of multiple linear regression, first it was decided to group the items of the constructs, turning them into one dependent variable, so as to enable the rotation of regression and test the influences that a construct has on the other.

\section{Results and Discussions}

The following are the key data found in this research to identify the main electronics consumer habits carried out by internet.

\subsection{Characteristics of the Sample}

Table 1 focuses socio-demographic variables stressing data split into gender, age and education.

Table 1. Gender, age and educationof respondents

\begin{tabular}{llll}
\hline Variables & Alternatives & Frequency & Percentage (\%) \\
\hline \multirow{2}{*}{ Gender } & Male & 163 & 36.38 \\
Overall total & Female & 285 & 63.62 \\
& & $\mathbf{4 4 8}$ & $\mathbf{1 0 0}$ \\
\hline \multirow{4}{*}{ Age } & From 18 to 25 years & 237 & 52.90 \\
& From 26 to 30 years & 103 & 22.99 \\
& From 31 to 35 years & 56 & 12.50 \\
& From 36 to 40 years & 28 & 6.25 \\
Overall total & From 41 to 45 years & 9 & 2.01 \\
& From 46 to 50 years & 5 & 1.12 \\
Education & Over 51 years & 10 & 2.23 \\
& & $\mathbf{4 4 8}$ & $\mathbf{1 0 0}$ \\
\hline \multirow{2}{*}{ Overall total } & High school & 10 & 2.23 \\
& Graduation & 336 & 75.00 \\
\hline
\end{tabular}

Source: Survey conducted (2013).

The sample of surveyed consumers features a female predominance (63.62\%), aged between 18 and 35 years in the age group $18-25$ years $(52.90 \%), 26$ to 30 years $(22.99 \%)$ and 31 to $35(12.50 \%)$. The age group with the least frequency identified corresponds to individuals over 36 years, totaling $11.61 \%$ of the sample. The education level of consumers surveyed has a higher proportion with regard to under-graduation, which corresponds to $75.00 \%$ of respondents, followed by graduates with $16.74 \%$. It is worth mentioning that the schooling variable may correspond to the fact that the individual is still studying or has completed his/her. 


\subsection{Main Habits Related to the Purchasing Adoption Process of Electronics Sold via Internet}

The following are the key data found in the research in order to identify the main electronics consumer habits carried out by internet. Table 2 corresponds to the last purchase made online and the frequency with which electronics purchases are usually made in virtual stores.

Table 2. Last purchase made over the Internet and frequency of purchases

\begin{tabular}{llll}
\hline Variables & Alternatives & Frequency & Percentage (\%) \\
\hline & Last month & 118 & 26.34 \\
& Last two months & 54 & 12.05 \\
Last purchase & Last three months & 33 & 7.37 \\
& Last four months & 30 & 6.70 \\
& Last five months & 22 & 4.91 \\
Overall total & Last six months & 191 & 42.63 \\
\hline \multirow{5}{*}{ Frequency of purchases } & Monthly & 24 & $\mathbf{1 0 0}$ \\
& Weekly & 17 & 5.36 \\
& Fimonthly & 110 & 3.79 \\
Overall total & Semiannually & 89 & 24.55 \\
\hline
\end{tabular}

Source: Survey conducted (2013).

As shown in Table 2, with regard to the last purchase made over the internet, it was identified that $42.63 \%$ had such action in the past six months, determining factor to products termed as consumer durables. Regarding this feature, the purchase of these products does not happenhabitually. An amount of $26.34 \%$ of the sample made a purchase in the last month and $31.30 \%$ made the last purchase within the course of two to five months.

The frequency with which purchases of electronics is made via internet is considered a key issue for this study, while it is apparent that most of the respondents usually buy electronics every six months (46.43\%).

Most respondents have an income up to R $\$ 2000.00$, with $38.62 \%$ of the sample with their own income between $\mathrm{R} \$ 1000.00$ to $\mathrm{R} \$ 2000.00$, followed by $31.03 \%$ with income below $\mathrm{R} \$ 1000.00$, totaling $69.65 \%$ with this characteristic. The amount spent on each purchase over the internet has greater relevance up to $\mathrm{R} \$ 500.00$ $(60.94 \%)$ because, according to data of the research exploratory phase, consumers still feel unconfidentabout certain purchases and try to become sure about the product quality before making the purchase.

It was also found that $50.18 \%$ of the interviewed female consumers make purchases over the internet every six months, a variable that has also achieved greater relevance compared to males $(39.88 \%)$. Both sexes also have a similar trait, which are monthly purchases, corresponding to $27.61 \%$ of the male consumers and $22.81 \%$ of female consumers.

\subsection{Multiple Linear Regression}

Multiple linear regression analysis is a statistical technique that can be used to analyze the relationship between a single independent variable and various dependent variables (Hair Jr. et al., 2005). For the present study, first it was decided to group the construct items of purchasing adoption process, turning it into a single variable, so as to enable the rotation of the multiple linear regression and test the behavior innovativenessinfluences on the purchasing adoption process. For data analysis, the Stepwise method was used. According to Hair Júnior et al. (1998), this method enables the analysis of the stepwise regression because it includes models in which the choice of predictor variables is accomplished by an automatic procedure. 
Table 3. ANOVA significance indexes of the test of influence of innovativeness behavior on the purchasing adoption process

\begin{tabular}{|c|c|c|c|c|c|c|}
\hline Model & & Sum of Squares & $\mathrm{df}$ & $\begin{array}{l}\text { Mean } \\
\text { Square }\end{array}$ & $\mathrm{F}$ & Sig. \\
\hline \multirow{3}{*}{1} & Regression & 57.757 & 1 & 57.757 & 169.952 & $.000^{\mathrm{h}}$ \\
\hline & Residues & 151.571 & 446 & .340 & & \\
\hline & Total & 209.329 & 447 & & & \\
\hline \multirow{3}{*}{2} & Regression & 68.767 & 2 & 34.383 & 108.853 & $.000^{\circ}$ \\
\hline & Residues & 140.562 & 445 & .316 & & \\
\hline & Total & 209.329 & 447 & & & \\
\hline \multirow{3}{*}{3} & Regression & 72.799 & 3 & 24.266 & 78.916 & $.000^{\circ}$ \\
\hline & Residues & 136.529 & 444 & .307 & & \\
\hline & Total & 209.329 & 447 & & & \\
\hline \multirow{3}{*}{4} & Regression & 74.758 & 4 & 18.690 & 61.525 & $.000^{\circ}$ \\
\hline & Residues & 134.571 & 443 & .304 & & \\
\hline & Total & 209.329 & 447 & & & \\
\hline
\end{tabular}

Note. Table 3 illustrates the significance indexes of ANOVA F-test.

Source: Survey conducted (2013).

When applying the Stepwise multiple regression, four regression models were achieved, the first containing Q06 variable only, the second containing variables Q06 and Q08, the third containing variables Q06, Q08 and Q03 and the fourth containing variables Q06, Q08, Q03 and Q07. After analysis, a model consisting of four variables having together the explanatory power $\left(\mathrm{R}^{2}\right)$ of $59.8 \%$ was found. The result of the ANOVA F-test was 169.952 , Durbin Watson equal to 1.894 and zero significance (Sig. 0000), yet it can be considered that the F significance level is below 5\%, showing the joint non-significance null hypothesis of the equation parameters may be rejected. Consequently, it can be asserted thatsuch model is significant. So, it can be noticed that the statistical variables have influence on the dependent variable and on the purchasing adoption process model as a whole.

The results of the multiple equation are shown below in Table 4 .

Table 4. Results of multiple equation

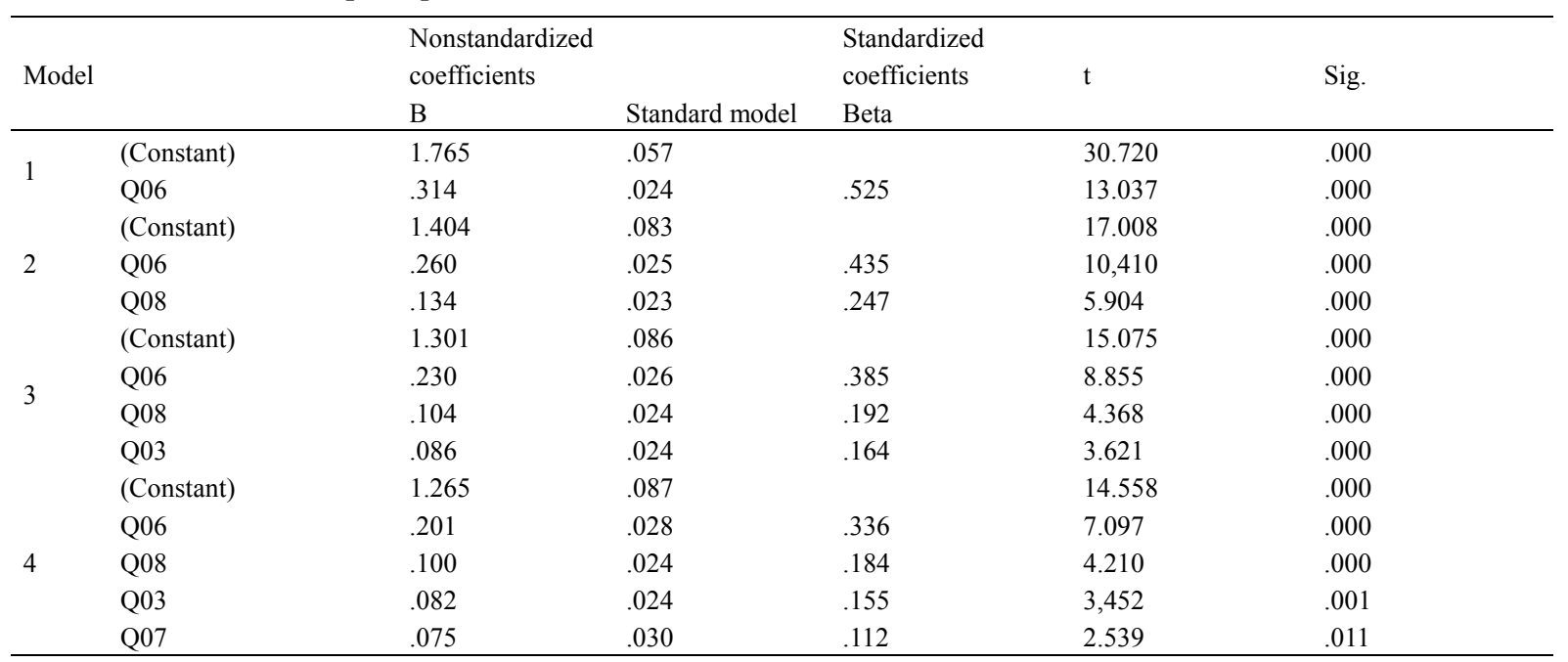

Source: Survey conducted (2013).

Based on Table 4, it is concluded that out of the variables recorded as independent, four remain in the analysis composing the final model, reaching an explanatory power $\left(\mathrm{R}^{2}\right)$ of $59.8 \%$, which implies that the innovativeness behavior influences the purchasing adoption process.

Among the items listed as independent variables, the one that showed a greater influence in relation to the construct of the purchasing adoption process was variable Q06-I usually buy innovative products because they combine with my image ( $\beta 0.336$ ), followed by Q08 - I enjoy products with innovative designs ( $\beta$ 0.184), as they 
are factors showing that the purchase itself involves issues related to the individual's personality and especially the formulation of his/her self-concept.

\section{Conclusions}

This study aimed at analyzing the influence of consumer behavior innovativeness on the purchasing adoption process. Among the specific objectives was defined: identifying the electronics consumer behavior innovativeness, as well as key influencing factors related to the purchasing adoption process.

Regarding the magnitude of innovativeness, it is observed that this research sample does not usually acquire innovative products before anyone else in their ring of friends do it, and the supply of innovative products alone is not enough to make this consumer feel attracted to the purchase. In this case, a purchase closing, consumers still need other stimuli. This situation was also descried on the studies of Vinson et al. (1977) and Bearden et al. (1985), for each person takes into consideration the global values of a certain reference group, which could be defined as a social influence.

Generally, respondents enjoy newly launched products, but enjoying does not mean buying them, and there is still a great distance between these two aspects. This issue differs from the study of Batory \& Neese (2005), because only the innovation is not a purchase criterion. Regarding the magnitude of self-concept, it became clear that interviewed consumers buy products for the benefits they bring and that the decision for such purchase is slightly related to their personal image.

The purchasing adoption process construct showed specificities in each analyzed dimension, concerning purchasing relevance, the research showed that the sample studied did not purchase an innovative product because it is essential or fun, but because it has some sort of benefit. The dimension of the symbolic value has negative traits in relation to the research objectives, because the purchase of innovative product does not lead to composing their personality traits, but it follows when the product brings new benefits. The dimensionsignificance of risk features that consumers care about the consequences of the purchase adoption and that the perception of risk is involved in the whole process. Accordingly, upon purchasing, consumers are sure about what they are doing and bear all purchasing risks. Such analyzed dimensions are also point out in the study of Engel et al. (1995), which describes that before the purchase itself, the costumer must go through a learning process, and during that process innumerous influencers can be cited.

From the analyses carried out and also the transcription of focus groups, it is possible to conclude that the findings of this research ratify the contents presented in the theoretical study review. Results derived from the application of multiple linear regression allow us to state that the consumer innovativeness behavior construct has an explanatory power $\left(\mathrm{R}^{2}\right)$ of $59.8 \%$ concerning the construct purchase adoption process construct. Within this context, consumer innovativeness behavior has a positive impact onpurchasing adoption process because consumers having a greater behavioral innovativeness possess similar traitsregarding purchasing of innovative electronics. Kazakeviciute \& Banyte (2012), on their study, also described that the purchasing process is influenced by the innovativeness behavior, mainly with the products that are sold online.

As a managerial contribution, it is worth noting that the results achieved in this research contribute to the development of new marketing strategies, enabling further development of actions towards higher profitability levels relative to sales of such product in the electronic environment, and further approaching even more consumers of the leading brands in the retail business. With regard to the consumer innovativeness behavior, the following characteristics were found:

Curiosity for the new: all newly released products in the market end upwakingthe consumer's curiosity, even if there is no actual adoption, there is a high need for information,because innovative products firstwake curiosity, and after generate a desire or a need.

Innovative design: product design also provedto be a significant factor upon thepurchase adoption because differentiated designs tend to be better liked by consumers and can also be the tie-breaking factor in the purchase decision. Consumers with a greater innovativeness behavior have a tendency to look for different ways to compose their own self-concept.

Purchase due to benefit: according to survey participants, in most cases purchases are made when the innovative product offers a specific benefit.In this context, it may be claimed that only an innovative product version is not enough for these consumers, the new product must have more features, benefits and advantages than the preceding model. The whole communication process of this new product in the electronic environment should be based on what it will provide during operation.

Social system: consumers with a more innovative behavior do not have social influence in relation to the 
adoption of new products, but tend to acquire innovative products focused on the formulation of their self-concept and their personal image. These consumers have a tendency to influence more than being influenced.

When facing that, marketing managers must pay attention to all the influencers' possibilities, interacting more with the consumer, turning their adoption process into a learning focused one, being able to show the products differentials and their main functionalities.

As a suggestion for future researches, it is indicated the reapplication of behavior innovativenessconstructs and the others studied in other areas of consumption, stressing other innovative products, allowingagreater understanding of consumer behavior and purchasing adoption process. As a result, it is suggested the application of this research as the goal to understand consumer consumption behavior of other innovative products, focusing on groups with different habits and customs, henceallowinga greater understanding of the topic, strengthening the understanding of consumer innovativeness behavior.

\section{References}

Alves-Mazzotti, A. J., \& Gewanddsznajer, F. (1999). O planejamento de pesquisas qualitativas. In. Os Métodos nas Ciências Naturais: pesquisa quantitativa e qualitativa. São Paulo: Thompson.

Arora, R. (1982). Validation of a S-O-R Model for situation, enduring, and response components of involvement. Journal of Marketing Research, 19, 505-516. https://doi.org/10.2307/3151723

Batory, S. S., \& Neese, W. (2005). Ethical Marketing Practices: An Investigation of Antecedents, Innovativeness and Business Performance. The Journal of American Academy of Business, Cambridge Number 2 March.

Bearden, W. O., Calcich, S. E., Retemeyer, R., \& Teel. J. E. (1985). An exploratory investigation of consumer innovativeness and interpersonal influences-University of South Carolina. Retrieved from $\mathrm{http} / / /$ acrwebsite.org/volumes/6469/volumes/v13/NA-13

Blake, B. F., Valdiserri, C. M., Neuendorf, K. A., \& Valdiserri, J. M. (2007). The Online Shopping Profile in the Cross-National Context: The Roles of Innovativeness and Perceived Innovation Newness. Journal of International Consumer Marketing, 19(3). https://doi.org/10.1300/J046v19n03_03

Caro, A., Mazzon, J. A., \& Caemmerer, B. W. M. (2010). Inovatividade, envolvimento, atitude e experiência na adoção da compra on-line. Revista de Administração Eletrônica, São Paulo, 51(6).

Chakrabarti, S., \& Baisya, R. K. (2009). Purchase of organic food: role of consumer innovativeness and personal influence related constructs. Journal Articles, 21.

Clarke, K., \& Belk, R. W. (1979). The effects of product involvement and task definition on anticipated consumer effort. Advances in Consumer Research, 6, 313-318.

Engel, J. F., Blackwell, R. D., \& Miniard, P. (1995). Consumer Behavior. Hindsale: The Dryden Press.

Goldsmith, R. E., \& Hofacker, C. F. (1991). Measuring consumer innovativeness. J Acad Mark Sci 1991. https://doi.org/10.1007/BF02726497

Grubb, E. L., \& Grathwohl, H. L. (1967). Consumer Self-Concept, Symbolism, and Market Behavior: A Theoretical Approach. Journal of Marketing. https://doi.org/10.2307/1249461

Hair Jr, J. F., Anderson, R, E., Tatham, R. L., \& Black, W. C. (1998). Multivariate Data Analysis (5th ed.) New Jersey: Prentice Hall.

Horn, S. A. (2009). Product adoption and innovation diffusion: the case of Japanese marketing to China. Asia Pacific Business Review. https://doi.org/10.1080/13602380802667361

Hynes, N., \& Lo, S. (2002). Innovativeness and Consumer Involvement in the Chinese Market. Singapore Management Review, 28(2).

Jain, K., \& Srinivasan, N. (1990). An empirical assessment of multiple operationalizations of involvement. Advances in Consumer Research, 17, 594-602. http://acrwebsite.org/volumes/7071/volumes/v17/NA-17

Kassarjian, H. H. (1971). Personality and Consumer Behavior: A Review. Journal of Marketing Research, VIII. https://doi.org/10.2307/3150229

Kazakeviciute, A., \& Banyte, J. (2012). The Relationship of Consumers Perceived Hedonic Value and Behavior, Inzinerine Ekonomika-Engineering Economics. http://dx.doi.org/10.5755/j01.ee.23.5.1975

Malhotra, N. K. (2012). Pesquisa de Marketing: uma orientação aplicada (6th ed.). Porto Alegre: Bookman. 
Marez, L., \& Verleye, G. (2004). Innovation diffusion: The need for more accurate consumer insight. Illustration of the PSAP scale as a segmentation instrument. Journal of Targeting, Measurement and Analysis for Marketing, 13(1), 32-49. https://doi.org/10.1057/palgrave.jt.5740130

Mcmahan, C., Hovland, R., \& Mcmillan, S. (2009). Online marketing communications: exploring online consumer behavior by examining gender differences and interactivity within internet advertising. Journal of Interactive Advertising. https://doi.org/10.1080/15252019.2009.10722163

OECD, Manual de Oslo. (2005). Proposta de Diretrizes para Coleta e Interpretação de Dados sobre Inovação Tecnológica.

Robertson, T. S. (1967). The process of innovation and the diffusion of innovation. Journal of Marketing, 31, 14-19. https://doi.org/10.2307/1249295

Rogers, E. M. (1983). Complex Adaptive Systems and the Diffusion of Innovations. The Innovation Journal: The Public Sector Innovation Journal, 10(3).

Schumpeter, J. A. (1942). Capitalism, socialismo, and democracy. New York e Londres, Harper e Brothers.

Strader, T. J., \& Hendrickson, A. R. (2001). Introduction to the Special Section on Marketing and Consumer Behavior in Electronic Markets, E-Service Journal. https://doi.org/10.1353/esj.2001.0007

Tajeddini, K., Trueman, M., \& Larsen, G. (2006). Examining the Effect of Market Orientation on Innovativeness. Journal of Marketing Management. https://doi.org/10.1362/026725706777978640

Tellis, G. J., Yin, E., \& Bell, S. (2009). Global Consumer Innovativeness: Cross-Country Differences and Demographic Commonalities. Journal of International Marketing, American Marketing Association, 17(2).

Tybout, A. M., \& Hauser, J. R. A. (1981). Marketing audit using a conceptual model of consumer behavior: application and evaluation. Journal of Marketing, 45. https://doi.org/10.2307/1251544

Vinson, D. E., Scott, J. E., \& Lamont, L. M. (1977). The Role of Personal Values in Marketing and Consumer Behavior. Journal of Marketing. https://doi.org/10.2307/1250633

Wang, Q., Dacko, S., \& Gad, M. (2008). Factors Influencing Consumers' Evaluation and Adoption Intention of Really-New Products or Services: Prior Knowledge, Innovativeness and Timing of Product Evaluation. Advances in Consumer Research.

Yang, K. (2010). The Effects of Technology Self-Efficacy and Innovativeness on Consumer Mobile Data Service Adoption between American and Korean Consumers. Journal of International Consumer Marketing, 22,117-127. https://doi.org/10.1080/08961530903476147

\section{Copyrights}

Copyright for this article is retained by the author, with first publication rights granted to the journal.

This is an open-access article distributed under the terms and conditions of the Creative Commons Attribution license (http://creativecommons.org/licenses/by/4.0/). 